\title{
PENGARUH PENGONDISIAN GELOMBANG OTAK ZONA ALFA PADA APERSEPSI PEMBELAJARAN TERHADAP MOTIVASI BELAJAR BIOLOGI SISWA KELAS XI IPA MAN 3 MAKASSAR
}

\author{
Andi Nurul Fatma ${ }^{1}$, Muljono Damopoliii ${ }^{2}$, Ahmad Afiif ${ }^{3}$ \\ 1,2,3Fakultas Tarbiyah dan Keguruan Universitas Islam Negeri Alauddin Makassar \\ 1,2,3Kampus: Jalan H. M. Yasin Limpo No. 36 Samata-Gowa, Sulawesi Selatan \\ Email: andinurulfatm4@gmail.com ${ }^{1}$, muljono.damopolii@uin-alauddin.ac.id ${ }^{2}$, \\ ahmad.afiif@uin-alauddin.ac.id ${ }^{3}$
}

\begin{abstract}
Abstrak:
Tujuan penelitian ini adalah untuk mengetahui realitas pengondisian gelombang otak zona alfa pada apersepsi pembelajaran, mengetahui gambaran motivasi belajar Biologi siswa, dan mengetahui pengaruh pengondisian gelombang otak zona alfa pada apersepsi pembelajaran terhadap motivasi belajar Biologi siswa kelas XI IPA MAN 3 Makassar. Penelitian ini termasuk penelitian Pre Experiment Design (Desain Eksperimen Lemah). Populasi penelitian ini adalah seluruh siswa kelas XI IPA MAN 3 Makassar tahun pelajaran 2015/2016, yang terdiri atas 4 kelas dengan jumlah siswa 105 orang. Penentuan sampel menggunakan teknik purposive sampling yang memungkinkan menetapkan sampel dua kelas, yaitu kelas XI IPA 1 sebagai kelas kontrol dan kelas XI IPA 2 sebagai kelas eksperimen. Instrumen penelitian yang digunakan adalah lembar observasi pengondisian gelombang otak zona alfa dan skala motivasi belajar siswa model Likert. Teknik analisis data yang digunakan yaitu analisis data statistik deskriptif dan statistik inferensial. Hasil penelitian dan analisis data terkait realitas pelaksanaan pengondisian gelombang otak zona alfa pada apersepsi pembelajaran siswa di kelas eksperimen adalah sebesar $100 \%$ sesuai pengamatan observer. Gambaran motivasi belajar Biologi siswa kelas eksperimen berkategori sangat tinggi sebesar 83,36\% dan kategori tinggi sebesar 13,63\%. Sedangkan motivasi belajar Biologi siswa kelas kontrol terdiri atas kategori sangat tinggi sebesar 52,00\%, tinggi 32,00\%, dan kategori rendah $16,00 \%$. Secara keseluruhan menunjukkan bahwa motivasi belajar Biologi siswa kelas eksperimen lebih tinggi daripada kelas kontrol. Hasil uji hipotesis dengan menggunakan uji $t$ dua sampel independen diperoleh nilai $-2,06>t^{\prime}>$ 2,06, di mana $\mathfrak{t}^{\prime}=3,45$ sehingga dapat disimpulkan bahwa terdapat pengaruh pengondisian gelombang otak zona alfa pada apersepsi pembelajaran terhadap motivasi belajar Biologi siswa.
\end{abstract}

\begin{abstract}
:
The purpose of this research is to know the alpha brain wave conditioning on learning apperception, to know the description of learning motivation of biology of students, and to know the effect of alpha brain wave conditioning on learning apperception on learning motivation of students of science class XI IPA MAN 3 Makassar. This research was Pre Experimental Design. The population of this research was all students of class XI IPA MAN 3 Makassar academic year 2015/2016, consisting of 4 classes with 105 students. Determination of sample using purposive sampling technique that allows to set sample of two classes, that was class XI IPA 1 as control class and class XI IPA 2 as experiment class. The research instrument used was observation sheet of alpha brain wave alpha and student motivation scale of Likert model. Data analysis techniques used were
\end{abstract}


descriptive statistics and inferential statistics. The results of research and data analysis related to the the implementation of alpha brain wave convergence on the apperception of student learning in the experimental class was $100 \%$ based on the observer observation. Biology motivation description of students of experimental class was categorized very high by $83.36 \%$ and high category of $13.63 \%$. While the motivation to learn Biology control class students consisted of very high category of $52.00 \%$, high $32.00 \%$, and low category $16.00 \%$. Overall showed that the motivation to learn Biology of experiment class students was higher than control class. The result of hypothesis test by using $t$ test of two independent samples obtained value $-2.06>t '>2.06$, where $t^{\prime}=3.45$. Tehrefore, it can be concluded that there was an influence of alpha brain wave conditioning on learning apperception to learning motivation Biology students.

\section{Kata kunci:}

Gelombang Otak, Zona Alfa, Apersepsi, Motivasi

PENDIDIKAN memiliki peranan yang sangat penting dalam meningkatkan kualitas sumber daya manusia seperti yang dimaksud dalam Undang-Undang RI Nomor 20 Tahun 2003 Bab II Pasal 3 tentang Sistem Pendidikan Nasional. Tantangan utama bangsa Indonesia dewasa ini dan di masa depan adalah kemampuan untuk meningkatkan kualitas sumber daya manusia dalam hal ini kualitas pendidikannya. Upaya yang dapat dilakukan untuk meningkatkan kualitas pendidikan sehingga bisa menghasilkan sumber daya manusia yang lebih berkualitas adalah sebuah keniscayaan, agar bangsa Indonesia menjadi bangsa yang produktif, efisien, dan memiliki kepercayaan diri yang kuat sehingga mampu bersaing dengan bangsa-bangsa lain dalam kehidupan global (Ismail, 2012).

Seorang pakar pendidikan Islam, Ahmad Tafsir (2010), menyatakan bahwa pendidikan merupakan hal yang sangat penting tidak hanya sebagai proses transfer informasi dari guru ke siswa, melainkan juga sekaligus sebagai proses memanusiakan manusia yakni proses penghayatan nilai dan norma. Dengan begitu, melalui pendidikan diharapkan terlahir sumber daya manusia yang berkualitas.

Perubahan tersebut dapat dilakukan melalui kegiatan belajar. Sebab, aktivitas belajar merupakan suatu proses perubahan tingkah laku atau kecakapan manusia. Kegiatan belajar merupakan kegiatan yang paling pokok dalam keseluruhan proses pendidikan. Hal ini mengandung arti bahwa berhasil tidaknya pencapaian tujuan pendidikan banyak bergantung kepada bagaimana proses belajar yang dialami oleh peserta didik atau siswa (Usman, 1993). Keberhasilan siswa dalam belajar tidak terlepas dari peranan dan tugas guru.

Untuk memaksimalkan keberhasilan guru dalam melaksanakan pembelajaran, maka guru perlu melakukan pengondisian gelombang otak zona alfa bagi siswa berupa mengondisikan siswa dalam keadaan yang nyaman dan rileks untuk belajar (Pasiak, 2003) . Pengondisian gelombang zona alfa dapat dilakukan dengan fun stroy atau musik. Hal ini akan memicu peserta didik termotivasi untuk belajar yang berarti adanya dorongan dalam diri peserta didik untuk melakukan kegiatan belajar. Do- 
rongan tersebut membuat siswa memiliki perhatian yang kuat untuk belajar lebih lanjut.

Berdasarkan fenomena di atas, maka tulisan ini bertujuan untuk mengungkap realitas pengondisian gelombang otak zona alfa pada apersepsi pembelajaran siswa kelas XI IPA MAN 3 Makassar, memberikan gambaran motivasi belajar Biologi siswa kelas XI IPA MAN 3 Makassar, dan menganalisis pengaruh pengondisian gelombang otak zona alfa pada apersepsi pembelajaran terhadap motivasi belajar Biologi siswa kelas XI IPA MAN 3 Makassar.

Terkait dengan tujuan yang ketiga, maka dapat dikemukakan di sini bahwa diduga kuat terdapat pengaruh signifikan pengondisian gelombang otak zona alfa pada apersepsi pembelajaran terhadap motivasi belajar Biologi peserta didik kelas XI IPA MAN 3 Makassar.

\section{LANDASAN TEORI}

\section{Gelombang Otak}

Otak manusia akan menerima pesan dan informasi yang datang sesuai dengan frekuensi gelombang otak. Penjelasan sederhananya, gelombang otak diibaratkan sebagai radio atau televisi. Prinsip dasar dari kedua alat elektronik tersebut yaitu adanya saluran atau sinyal yang dapat menghantarkan pesan melalui gelombang (Muhammad, 2011).

Dapat disimpulkan bahwa otak setiap saat menghasilkan impuls-impuls listrik. Aliran listrik ini, yang lebih dikenal sebagai gelombang otak, dengan dua cara yaitu amplitudo dan frekuensi. Amplitudo adalah besarnya daya impuls listrik yang diukur dalam satuan micro volt. Frekuensi adalah kecepatan emisi listrik yang diukur dalam cycle per detik atau hertz. Frekuensi impuls menentukan jenis gelombang otak yaitu beta, alfa, theta, dan delta. Jenis atau kombinasi jenis gelombang otak akan menentukan kondisi kesadaran pada suatu saat.

Zona alfa (Alpha Zone) adalah salah satu gelombang otak dengan frekuensi 7-13 Hz. Kondisi gelombang otak zona alfa dipahami sebagai tahap paling iluminatif (cemerlang) dari proses kreatif otak seseorang. Kondisi ini dikatakan sebagai kondisi paling baik untuk belajar, karena neuron (sel saraf) sedang berada dalam suatu harmoni (keseimbangan) yaitu ketika sel-sel saraf seseorang melakukan tembakan impuls listrik secara bersamaan dan juga beristirahat secara bersamaan sehingga timbul keseimbangan yang mengakibatkan kondisi relaksasi seseorang. Hal ini menimbulkan adanya efisiensi pada jalur saraf sehingga kondisi tersebut sangat tepat untuk melakukan sugesti (Chatib, 2014).

Berdasarkan pengertian di atas dapat disimpulkan bahwa gelombang otak yang tepat untuk belajar yakni dalam gelombang otak zona alfa. Kondisi zona alfa merupakan keadaan terbaik siswa untuk belajar. Seseorang yang sedang masuk dalam kondisi alfa akan mengalami kondisi yang relaks tetapi waspada, seperti sedang melamun, tetapi sebenarnya sedang berpikir. Kondisi tersebut disebabkan karena otak bekerja dengan relaks. Kondisi alfa merupakan kondisi yang tepat untuk belajar. Para 
guru semestinya mengetahui dengan baik zona kondisi alfa ini karena terkait dengan masuknya arus informasi ke dalam otak siswa. Betapa pun bagusnya strategi pembelajaran yang dilaksanakan oleh guru, tetapi siswa keluar dari zona alfa maka informasi tidak akan pernah masuk ke dalam memori siswa.

\section{Apersepsi Pembelajaran}

Apersepsi berasal dari kata apperception, yang berarti menafsirkan buah pikiran. Jadi, apersepsi adalah menyatukan dan mengasimilasi suatu pengalaman dengan pengalaman yang telah dimiliki sehingga mampu memahami dan menafsirkannya (Nasution, 2010).

Berdasarkan hal tersebut dapat disimpulkan bahwa apersepsi harus dilakukan oleh guru dalam memulai materi pembelajaran. Apersepsi dapat dilakukan dengan berbagai tahapan yang pada intinya bertujuan untuk menarik perhatian siswa dengan menghubungkan pemahaman awal siswa dengan pelajaran yang akan dipelajari. Dengan adanya apersepsi maka dapat memberikan dasar awal siswa untuk mempelajari materi yang baru, dengan demikian maka apersepsi dapat memberikan kemudahan siswa dalam belajar.

\section{Motivasi Belajar}

Motivasi belajar adalah keseluruhan daya penggerak di dalam diri siswa yang menimbulkan kegiatan belajar, yang menjamin kelangsungan dari kegiatan belajar dan memberi arah pada kegiatan belajar, sehingga tujuan yang dikehendaki dapat tercapai. Berdasarkan pendapat-pendapat di atas, dapat disimpulkan bahwa motivasi belajar adalah dorongan atau kekuatan dalam diri siswa yang menimbulkan kegiatan serta arah belajar untuk mencapai tujuan yang dikehendaki siswa (Dimyati, 2001; Djamarah, 2008).

Berdasarkan uraian di atas dapat disimpulkan bahwa motivasi belajar dalam diri seseorang dapat didorong oleh beberapa aspek, di antaranya keadaan yang mendorong tingkah laku yaitu perilaku belajar akibat dorongan dan kebutuhan dalam belajar. Tingkah laku yang didorong oleh keadaan yaitu adanya penghargaan dalam belajar atau adanya kegiatan dan kondisi yang menarik dalam belajar sehingga mendorong untuk belajar. Tujuan dari tingkah laku yaitu perilaku belajar karena adanya harapan atau cita-cita di masa depan.

\section{METODE PENELITIAN}

\section{Jenis dan Desain Penelitian}

Jenis penelitian ini adalah Pre Experiment Design (Desain Eksperimen Lemah). Berdasarkan masalah dan tujuan pembelajaran, maka desain penelitian yang sesuai adalah Intact-Group Comparison. Pada desain ini digunakan dua kelas pararel, satu kelas digunakan untuk eksperimen yang diberi perlakuan dan satu kelas lainnya sebagai kelas kontrol yang tidak diberi perlakukan (Emzir, 2007; Mustami, 2016; Sugiyono, 2008). 


\section{Lokasi penelitian}

Penelitian ini dilaksanakan di Madrasah Aliyah Negeri 3 Makassar. Alamat Jalan Perintis Kemerdekaan KM 15 Daya, Kec. Biringkanaya, Makassar, Sulawesi Selatan.

\section{Populasi dan sampel}

Tabel 3.1 Jumlah Populasi

\begin{tabular}{|c|l|c|}
\hline No & Kelas XI IPA & Jumlah Siswa \\
\hline 1 & XI IPA 1 Putri & 25 \\
\hline 2 & XI IPA 2 Putri & 22 \\
\hline 3 & XI IPA 3 Putri & 23 \\
\hline 4 & XI IPA 4 Putra & 35 \\
\hline & Jumlah & 105 \\
\hline
\end{tabular}

Jumlah populasi dari semua jumlah siswa kelas XI IPA sebanyak 105 orang peserta didik. Teknik pengambilan sampel yang digunakan pada penelitian ini adalah purposive sampling (Arikunto, 2000; Narbuko, 2013). Sampel dipilih berdasarkan pertimbangan-pertimbangan pelaksanaan penelitian yaitu kelas eksperimen dan kelas kontrol yang merupakan kelas rekomendasi pihak sekolah dengan pertimbangan sesuai dengan tujuan penelitian dan antara kelas eksperimen dengan kelas kontrol tidak terdapat perbedaan gender dan pengelompokan kelas tidak berdasarkan kemampuan akademik. Sampel pada penelitian ini adalah siswa kelas XI IPA 2 Putri sebagai kelas eksperimen yang berjumlah 22 orang siswa dan siswa kelas XI IPA 3 Putri sebagai kelas kontrol yang berjumlah 25 orang.

\section{Instrumen penelitian}

\section{Skala}

Skala yang digunakan adalah skala model Likert. Skala motivasi belajar disusun berdasarkan teori Morgan. Morgan mengemukakan bahwa motivasi bertalian oleh tiga hal, yaitu keadaan yang mendorong tingkah laku (motivation states), tingkah laku yang didorong oleh keadaan tersebut (motivated behavior), dan tujuan dari tingkah laku tersebut. Dalam skala ini, pernyataan-pernyataan yang ada terdiri atas dua jenis pernyataan, yaitu pernyataan positif dan negatif dengan jumlah item yang digunakan sebanyak 28 item.

\section{Lembar Observasi}

Lembar observasi adalah lembar kerja yang digunakan untuk mengobservasi dan mengukur tingkat pengondisian gelombang otak zona alfa pada apersepsi pembelajaran terhadap motivasi belajar Biologi siswa kelas eksperimen XI IPA 2 MAN 3 Makassar. 


\section{HASIL DAN PEMBAHASAN}

\section{Realitas Pengondisian Gelombang Otak Zona Alfa pada Apersepsi Pembelajaran Siswa Kelas XI IPA MAN 3 Makassar}

Pelaksanaan pengondisian gelombang otak zona alfa didasarkan pada penerapan rencana pelaksanaan pembelajaran (RPP) dengan sintaks pembelajaran pengondisian gelombang otak. Munif Chatib (2014) dalam buku "Gurunya Manusia" dan menyebutkan bahwa hal ini dilaksanakan dengan stimulus musik klasik dan fun story yang berdasarkan pedoman observasi, terdiri atas 9 pernyataan yang dinilai oleh 2 observer penelitian yakni Nurmawang (Guru Mata Pelajaran Biologi MAN 3 Makassar) dan Nurmala Indah Sari (rekan sejawat mahasiswa Jurusan Pendidikan Biologi). Setelah dilaksanakan pengondisian zona alfa pada kelas eksperimen kelas XI IPA 2 kemudian dilakukan analisis deskriptif pelaksaan pengondisian zona alfa sehingga gambaran umum tentang pengondisian gelombang otak zona alfa pada apersepsi pembelajaran disajikan sebagai berikut.

Dari analisis di atas diketahui pelaksanaan pengondisian zona alfa pada kelompok eksperimen kelas XI IPA 2 diperoleh nilai persentase skor pelaksanaan pengondisian zona alfa sebesar $100 \%$ yang artinya sintaks skor pelaksanaan terlaksana seluruhnya sesuai dengan pengamatan observer.

\section{Gambaran Motivasi Belajar Biologi Siswa Kelas XI IPA MAN 3 Makassar}

Berdasarkan hasil observasi awal dan wawancara langsung dengan salah seorang guru mata pelajaran Biologi kelas XI IPA MAN 3 Makassar, Nurmawang, diperoleh gambaran motivasi belajar Biologi siswa pada umumnya bervariasi, tetapi terdapat beberapa kelompok siswa yang cenderung tergolong motivasi rendah yang ditunjukkan dengan kurangnya partisipasi aktif dalam mengikuti kegiatan belajar di sekolah.

\section{Pengaruh Pengondisian Gelombang Otak Zona Alfa pada Apersepsi Pembelajaran terhadap Motivasi Belajar Biologi Siswa Kelas XI IPA MAN 3 Makassar}

\section{Analisis Deskriptif}

\section{Deskripsi Data Kelas Eksperimen (XI IPA 2)}

Setelah dilakukan penelitian dan pengolahan data hasil penelitian pada kelas eksperimen yang diberikan pengondisian gelombang otak zona alfa pada apersepsi pembelajaran terhadap motivasi belajar Biologi siswa maka diperoleh data sebagai berikut:

Tabel 4.2. Statistik deskriptif motivasi belajar Biologi kelas eksperimen

\begin{tabular}{|l|c|}
\hline Statistik deskriptif & Nilai \\
\hline Jumlah sampel & 22 \\
\hline Skor maksimum & 114,00 \\
\hline Skor minimum & 90,00 \\
\hline
\end{tabular}




\begin{tabular}{|l|c|}
\hline Rata-rata & 101,27 \\
\hline Standar deviasi & 6,48 \\
\hline Varians & 41,99 \\
\hline Koefisien Variasi & $6,39 \%$ \\
\hline
\end{tabular}

Selanjutnya data motivasi belajar Biologi siswa pada kelas eksperimen yaitu kelas XI IPA 2 dapat dilihat bahwa setelah diberikan perlakuan khusus berupa pengondisian gelombang otak zona alfa pada apersepsi pembelajaran diperoleh kategori motivasi belajar Biologi siswa yang disajikan dalam tabel berikut:

Tabel 4.3 Data motivasi belajar kelas eksperimen

\begin{tabular}{|c|c|c|c|c|}
\hline No. & Interval & Jumlah & Persentase & Kategori \\
\hline 1 & $95-116$ & 19 & 86,36 & Sangat tinggi \\
\hline 2 & $73-94$ & 3 & 13,63 & Tinggi \\
\hline 3 & $51-72$ & 0 & 0 & Rendah \\
\hline 4 & $29-50$ & 0 & 0 & Sangat rendah \\
\hline \multicolumn{2}{|c|}{ Jumlah } & 22 & $100 \%$ & \\
\hline
\end{tabular}

Dari tabel di atas dipahami bahwa data yang diperoleh setelah perlakuan terdapat jumlah siswa yang memperoleh motivasi belajar sangat tinggi sebanyak 19 siswa dengan persentase $86,36 \%$, motivasi belajar tinggi sebanyak 3 siswa dengan persentase $13,63 \%$, yang disajikan dalam histogram berikut ini:

2. Deskripsi Data Kelas Kontrol (XI IPA 1)

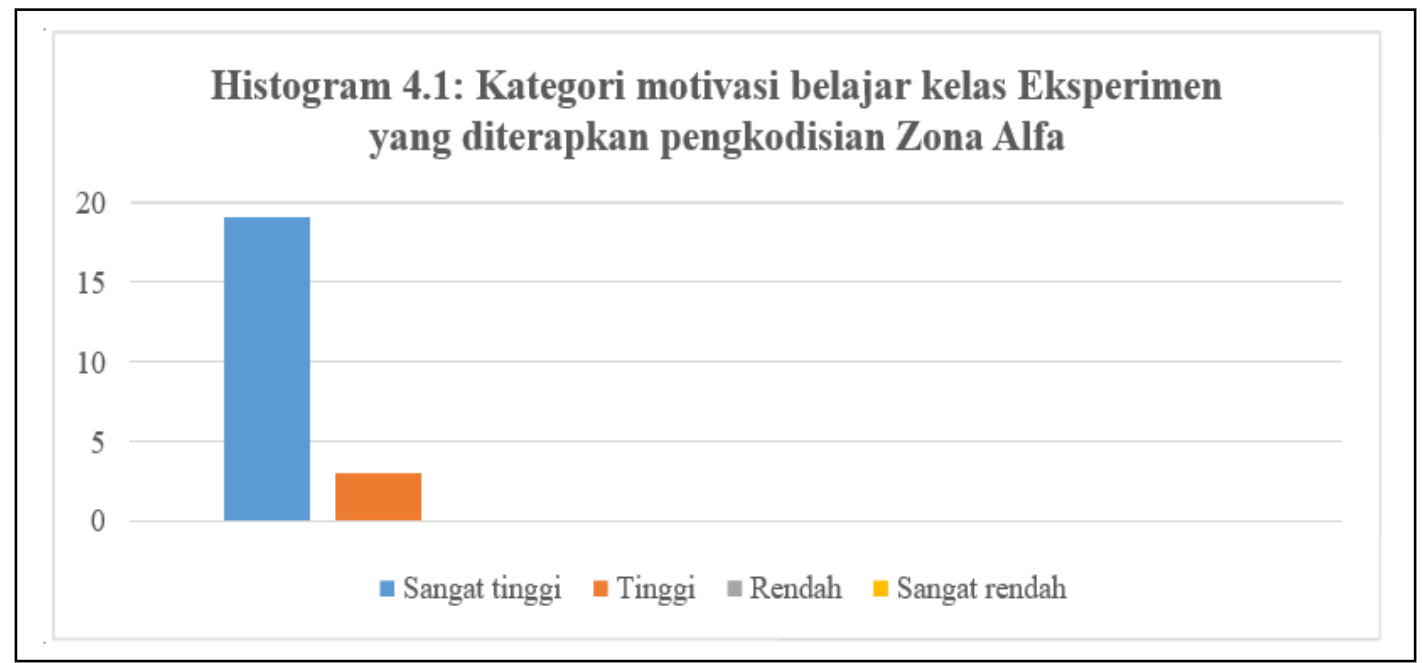

Setelah diberikan tes motivasi belajar pada kelas kontrol yang diajar dengan metode konvensional maka diperoleh data statistik deskriptif yang ditunjukkan pada tabel di bawah ini: 
Tabel 4.4 Statistik deskriptif motivasi belajar Biologi siswa kelas kontrol

\begin{tabular}{|l|c|}
\hline Statistik deskriptif & Nilai \\
\hline Jumlah sampel & 25 \\
\hline Skor maksimum & 108,00 \\
\hline Skor minimum & 67,00 \\
\hline Rata-rata & 91,52 \\
\hline Standar deviasi & 11,66 \\
\hline Varians & 135,95 \\
\hline Koefisien variasi & $12,74 \%$ \\
\hline
\end{tabular}

Data motivasi pada kelas kontrol yang tidak diterapkan pengondisian gelombang otak zona alfa dengan metode konvensional yaitu kelas XI IPA 1 dapat dilihat pada tabel berikut:

Tabel 4.5 Data motivasi belajar kelas kontrol

\begin{tabular}{|c|c|c|c|c|}
\hline No. & Interval & Jumlah & Persentase & Kategori \\
\hline 1 & $95-116$ & 13 & 52.00 & Sangat tinggi \\
\hline 2 & 73-94 & 8 & 32.00 & Tinggi \\
\hline 3 & $51-72$ & 4 & 16.00 & Rendah \\
\hline 4 & $29-50$ & 0 & 0 & Sangat rendah \\
\hline \multicolumn{2}{|c|}{ Jumlah } & 25 & $100 \%$ & \\
\hline
\end{tabular}

Data tersebut diperoleh pada kelas kontrol setelah diukur motivasi belajar Biologi siswa dengan menggunakan skala motivasi belajar terdapat jumlah siswa yang memperoleh motivasi belajar sangat tinggi sebanyak 13 siswa dengan persentase $52.00 \%$, sebanyak 8 siswa dengan persentase $32.00 \%$ dengan motivasi belajar tinggi, motivasi belajar rendah sebanyak 4 siswa dengan persentase $16,00 \%$, yang disajikan dalam histogram berikut ini:

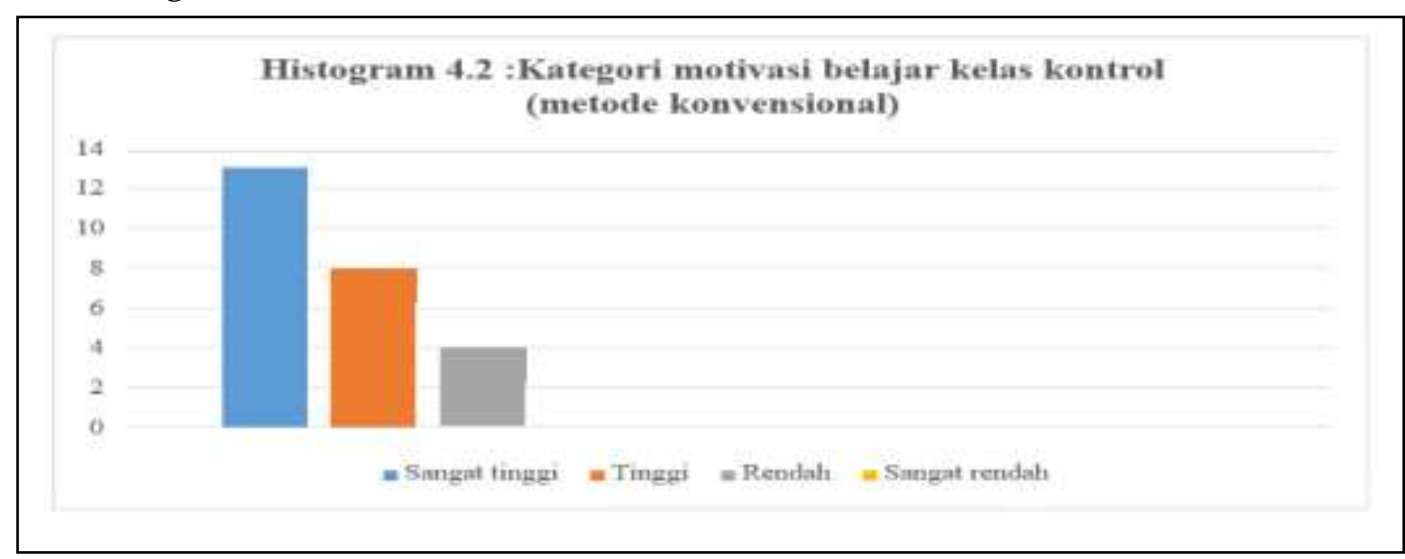




\section{Hasil Uji Prasyarat Analisis Penelitian}

1. Uji Normalitas

Uji normalitas dilakukan untuk mengetahui apakah data motivasi belajar Biologi peserta didik yang diperoleh, baik dari kelas eksperimen maupun kelas kontrol berdistribusi normal atau tidak. Pada penelitian ini, pengujian normalitas data dilakukan dengan menggunakan uji Kolmogorov-Smirnov pada taraf signifikansi $a=0,05$. Adapun hasil perhitungan uji normalitas dalam penelitian ini, sebagai berikut:

\section{Kelas Eksperimen}

Tabel 4.6 Hasil uji normalitas nilai motivasi belajar Biologi peserta didik kelas eksperimen

\begin{tabular}{|c|c|c|}
\hline$D_{\text {hitung }}$ & $D_{\text {tabel }}$ & Keterangan \\
\hline 0,079 & 0,281 & Norma \\
\hline
\end{tabular}

Berdasarkan tabel 4.6 diperoleh nilai Dhitung sebesar 0,079 dan $D_{\text {tabel sebesar }}$ 0,281 pada taraf signifikan $a=0,05$. Dengan demikian, dapat dilihat bahwa nilai Dhitung lebih kecil dari $D_{\text {tabel. }}$ Hal ini menunjukkan bahwa data tersebut berdistribusi normal.

Pengolahan data dengan bantuan program IBM SPSS juga menunjukkan hasil yang sama dengan hasil pada tabel 4.6. Hal ini dapat ditunjukkan sebagai berikut:

Tabel 4.7 Uji normalitas motivasi belajar menggunakan program SPSS pada kelas eksperimen

\begin{tabular}{|c|c|c|c|}
\hline \multirow{2}{*}{ Tests of Normality } \\
\hline \multirow{3}{*}{ Frekuensi } & \multicolumn{3}{|c|}{ Kolmogorov-Smirnov ${ }^{\mathrm{a}}$} \\
\cline { 2 - 4 } & Statistic & Df & Sig. \\
\cline { 2 - 4 } & 0,109 & 22 & 0,200 \\
\hline
\end{tabular}

Berdasarkan tabel 4.7 untuk data pada kelas eksperimen yang diterapkan dengan perlakuan pengondisian gelombang otak zona alfa terdistribusi normal. Hal ini dapat dilihat dari nilai signifikan menggunakan metode Kolmogorov-Smirnov diperoleh nilai signifikan sebesar 0,200 lebih besar dari 0,05 (sig. > 0,05) lebih besar dari 0,05 (sig. > 0,05). Dengan begitu, dapat ditarik kesimpulan bahwa data tersebut berdistribusi normal. Untuk memperkuat kesimpulan di atas, data hasil motivasi belajar Biologi siswa dibuat dalam bentuk diagram normal QQ Plot pada kelas eksperimen, seperti pada pada gambar 4.3.

Dari gambar 4.3 diperoleh penjelasan bahwa titik-titik yang berada di sekitar garis merupakan nilai hasil belajar siswa kelas eksperimen. Semakin banyak jumlah titik-titik tersebut, maka data motivasi belajar Biologi siswa semakin bervariasi. Selain itu, pada gambar 4.3 ditunjukkan sebuah garis linear. Garis tersebut merupakan garis distribusi normal data. Semakin dekan titik-titik data pada garis, maka data tersebut juga semakin normal. 


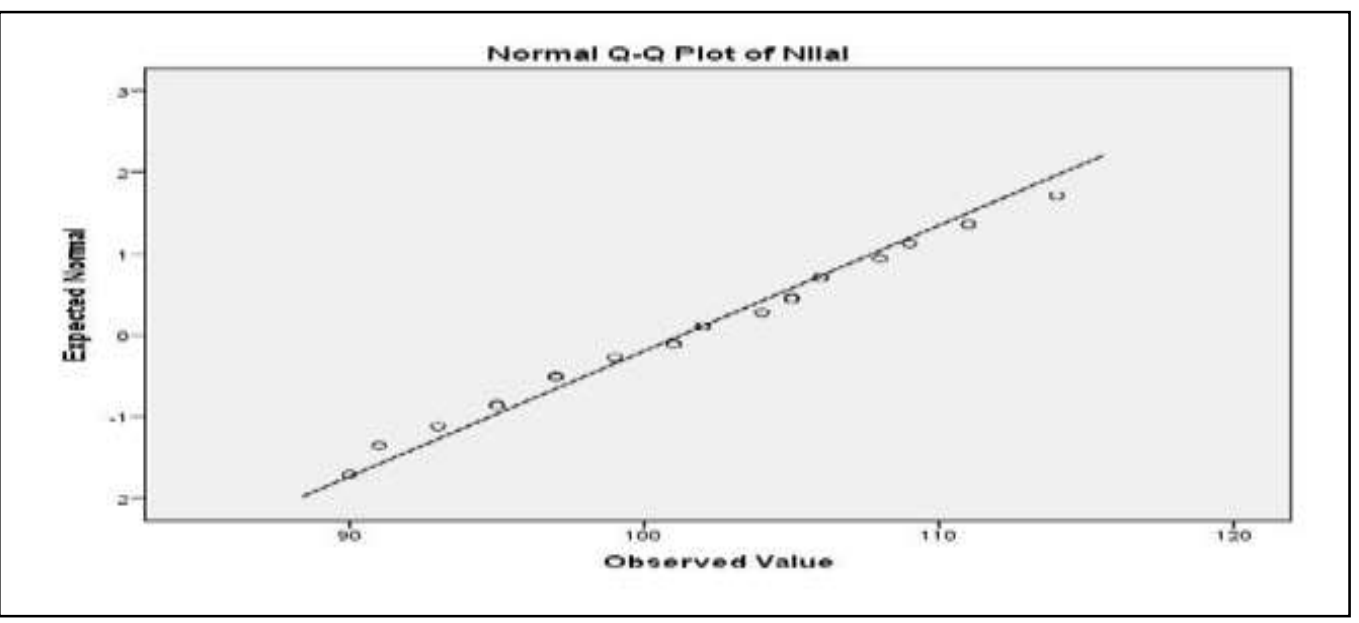

Gambar 4.3 Grafik distribusi normal nilai motivasi belajar Biologi siswa kelas eksperimen

\section{Kelas Kontrol}

Hasil perhitungan uji normalitas untuk data motivasi belajar Biologi siswa kelas eksperimen secara manual dapat dipaparkan berikut ini:

Tabel 4.8. Hasil uji normalitas nilai motivasi belajar Biologi siswa kelas kontrol

\begin{tabular}{|c|c|c|}
\hline$D_{\text {hitung }}$ & $\mathrm{D}_{\text {tabel }}$ & Keterangan \\
\hline 0,134 & 0,264 & Norma \\
\hline
\end{tabular}

Berdasarkan tabel 4.8 diperoleh nilai Dhitung sebesar 0,134 dan Dtabel sebesar 0,264 pada taraf signifikan $\alpha=0,05$. Dengan demikian, dapat dilihat bahwa nilai Dhitung lebih kecil dari $D_{\text {tabel. }}$ Hal ini menunjukkan bahwa data tersebut berdistribusi normal.

Pengolahan data dengan bantuan program IBM SPSS juga menunjukkan hasil yang sama dengan hasil pada tabel 4.8. Hal ini dapat ditunjukkan sebagai berikut:

Tabel 4.9 Uji normalitas motivasi belajar Biologi siswa menggunakan program

SPSS versi 20 for Windows pada kelas kontrol

\begin{tabular}{|c|c|c|c|}
\hline \multicolumn{4}{|c|}{ Tests of Normality } \\
\hline \multirow{3}{*}{ Frekuensi } & \multicolumn{3}{|c|}{ Kolmogorov-Smirnov $^{\mathrm{a}}$} \\
\cline { 2 - 4 } & Statistic & Df & Sig. \\
\cline { 2 - 4 } & 0,137 & 25 & 0,200 \\
\hline
\end{tabular}

Berdasarkan tabel 4.9 untuk data pada kelas eksperimen yang diterapkan dengan perlakuan pengondisian gelombang otak zona alfa terdistribusi normal. Hal ini dapat dilihat dari nilai signifikan menggunakan metode Kolmogorov-Smirnov sehingga diperoleh nilai signifikan sebesar 0,200 lebih besar dari 0,05 (sig. > 0,05) lebih besar dari 0,05 (sig. > 0,05). Dengan begitu, dapat disimpulkan bahwa data tersebut berdistribusi normal.

Untuk memperkuat kesimpulan di atas, data hasil motivasi belajar siswa dibuat dalam bentuk diagram normal QQ Plot pada kelas kontrol. 


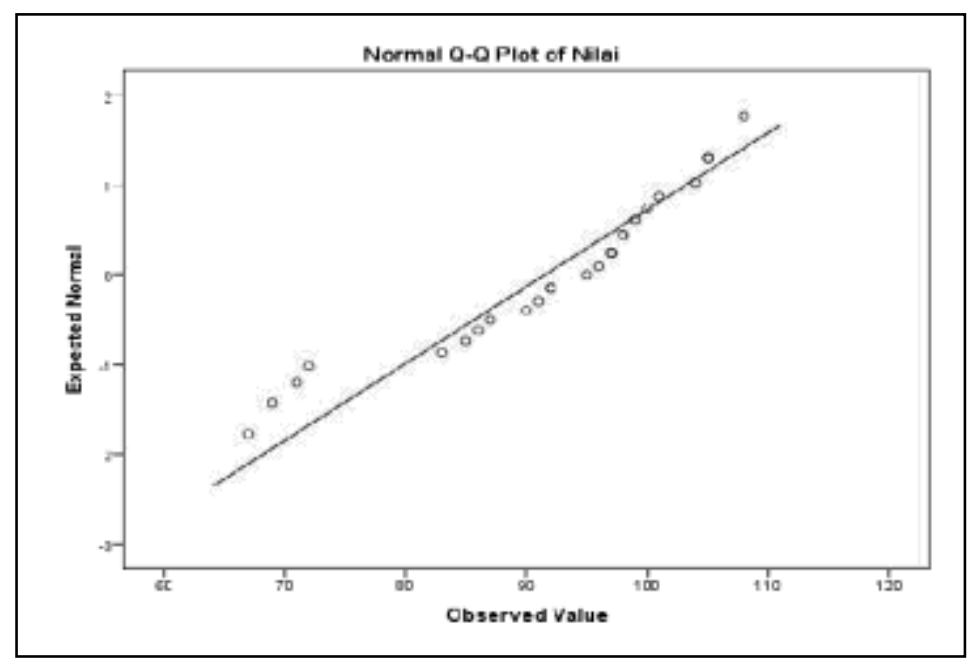

Gambar 4.4 Grafik distribusi normal nilai hasil belajar Biologi siswa kelas kontrol

Dari gambar 4.4 diperoleh penjelasan bahwa titik-titik yang berada di sekitar garis merupakan nilai motivasi belajar siswa kelas kontrol. Semakin banyak jumlah titik-titik tersebut, maka data motivasi belajar Biologi siswa semakin bervariasi.

Berdasarkan data di atas, dapat ditunjukkan bahwa kelas kontrol memiliki 21 variasi nilai motivasi Biologi, karena pada gambar terdapat 21 titik. Berdasarkan gambar dapat diamati bahwa titik-titik tersebut rata-rata berkumpul pada garis linear, sehingga dapat disimpulkan bahwa nilai motivasi Biologi siswa kelas kontrol berdistribusi normal.

\section{Uji Homogenitas}

Untuk mengetahui tingkat homogen data dalam penelitian ini, baik kelas eksperimen maupun kelas kontrol maka digunakan uji $\mathrm{F}_{\text {maks }}$ yakni dengan membandingkan nilai varians dari kedua kelas. Hasil perhitungan uji homogenitas dapat ditunjukkan pada tabel berikut:

Tabel 4.10 Hasil perhitungan uji homogenitas nilai motivasi Biologi

\begin{tabular}{|c|c|c|}
\hline $\mathbf{F}_{\text {Hitung }}$ & $\mathbf{F}_{\text {Tabel }}$ & Keterangan \\
\hline 3,23 & 2,05 & Tidak Homogen \\
\hline
\end{tabular}

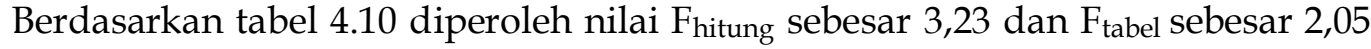
pada taraf signifikan $a=0,05$. Dengan demikian, dapat dilihat bahwa nilai $F_{\text {hitung }}$ lebih besar dari $F_{\text {tabel. }}$ Hal ini menunjukkan bahwa kedua kelas memiliki varians yang tidak sama atau tidak homogen.

Selain menggunakan analisis secara manual, Uji homogenitas pada penelitian ini dilakukan pula dengan menggunakan program SPSS versi 20 for Windows melalui metode Levene Statistic pada taraf signifikansi $\alpha=0,05$ dari hasil analisis variasi untuk data yang sama yaitu sebanyak 22 orang dari kelas eksperimen yang diberikan perlakuan pada kegiatan belajar dengan pengondisian gelombang otak zona alfa dan 25 orang dari kelas kontrol yang tanpa perlakuan pengondisian gelombang otak zona 
alfa (metode konvensional), sehingga diperoleh hasil yang ditunjukkan pada tabel 4.9 berikut:

Tabel 4.11. Hasil perhitungan uji homogenitas motivasi belajar siswa dengan program SPSS versi 20 for Windows

\begin{tabular}{|c|c|c|c|c|c|}
\hline \multicolumn{6}{|c|}{ Test of Homogeneity of Variance } \\
\hline & & Levene Statistic & df1 & df2 & Sig. \\
\hline $\begin{array}{l}\text { Motivasi } \\
\text { belajar siswa }\end{array}$ & $\begin{array}{c}\text { Based on } \\
\text { Mean }\end{array}$ & 5,427 & 1 & 45 & 0,024 \\
\hline
\end{tabular}

Berdasarkan tabel 4.11 dapat diinterpretasikan dengan memilih salah satu statistik yang didasarkan pada rata-rata (based on mean), jika nilai signifikansi yang diperoleh lebih besar dari 0,05, maka varians setiap sampel sama (homogen). Begitu pun sebaliknya, jika nilai signifikan lebih kecil dari 0,05, maka varians setiap sampel tidak sama atau tidak homogen. Dari tabel pengujian di atas, dapat dilihat semua nilai signifikansi pada kolom Levene Statistic lebih kecil dari 0,05. Dengan demikian dapat dikatakan bahwa varians setiap sampel tidak sama (tidak homogen).

\section{Uji Hipotesis}

Berdasarkan uji asumsi dasar, maka diketahui bahwa data-data motivasi belajar untuk kedua kelas berdistribusi normal dan memiliki varians yang tidak sama, maka analisis dilanjutkan dengan uji hipotesis. Uji hipotesis yang digunakan adalah uji-t dua sampel independent.

Tabel 4.12. Hasil deskriptif nilai motivasi belajar Biologi siswa kelas eksperimen dan kelas kontrol

\begin{tabular}{|l|c|c|}
\hline \multicolumn{1}{|c|}{ Parameter } & Kelas Eksperimen & Kelas Kontrol \\
\hline Jumlah sampel $(\mathrm{N})$ & 22 & 25 \\
\hline Rata-rata & 101,27 & 91,52 \\
\hline Standar deviasi $(\mathrm{S})$ & 6,48 & 11,66 \\
\hline Varians $\left(\mathrm{S}^{2}\right)$ & 6,48 & 135,95 \\
\hline
\end{tabular}

\section{Kriteria Pengujian}

Dalam pengujian ini digunakan kriteria, Ho diterima jika:

$$
-\frac{w_{1} t_{1}+w_{2} t_{2}}{w_{1}+w_{2}}<t^{\prime}<\frac{w_{1} t_{1}+w_{2} t_{2}}{w_{1}+w_{2}}
$$

Dimana:

$$
w_{1}=\frac{s_{1}^{2}}{n_{1}}=1,90
$$




$$
\begin{aligned}
& w_{2}=\frac{s_{2}^{2}}{n_{2}} \equiv 5,4.3 \\
& t_{1}=t_{\left(1-\frac{1}{2} \alpha\right),\left(n_{1}-1\right)}=t_{\left(1-\frac{1}{2} 0.05\right),(15-1)}=t_{(0.975)_{4}(14)}=\dot{z . v} \\
& t_{2}=t_{\left(1-\frac{1}{2} \alpha\right),\left(n_{2}-1\right)}=t_{\left(1-\frac{1}{2} 0.05\right),(15-1)}=t_{(0.975)_{(}(14)}=t \cdots \\
& \qquad \frac{w_{1} t_{1}+w_{2} t_{2}}{w_{1}+w_{2}}=\frac{3.93+11.10}{7,33}=2,06
\end{aligned}
$$

Berdasarkan hasil analisis yang diperoleh, maka ditunjukkan bahwa $-2,06>\mathbf{t}^{\prime}$ 2,06, dimana $t^{\prime}=3,45$ sehingga dapat disimpulkan bahwa terdapat pengaruh pengondisian gelombang otak zona alfa pada apersepsi pembelajaran terhadap motivasi belajar Biologi siswa.

Selain menggunakan analisis secara manual dan untuk memperkuat hasil analisis yang diperoleh, maka dilakukan pula analisis menggunakan SPSS sebagaimana dipaparkan berikut.

Tabel 4.13: Hasil analisis hipotesis (uji-t dua sampel independen) dengan program IBM SPSS

\begin{tabular}{|l|l|r|r|r|r|}
\hline \multicolumn{2}{|c|}{} & \multicolumn{2}{|c|}{$\begin{array}{c}\text { Levene's Test } \\
\text { for }\end{array}$} & \multicolumn{2}{|c|}{ t-test for Equality of Means } \\
\cline { 3 - 6 } & F & Sig. & T & Sig. (2-tailed) \\
\hline \multirow{2}{*}{ NILAI } & $\begin{array}{l}\text { Equal variances } \\
\text { assumed }\end{array}$ & 5,427 & 0,024 & 3,476 & 0,001 \\
\cline { 2 - 6 } & $\begin{array}{l}\text { Equal variances not } \\
\text { assumed }\end{array}$ & & & 3,597 & 0,001 \\
\hline
\end{tabular}

Berdasarkan hasil keluaran program SPSS di atas, dapat dilihat bahwa nilai levene's test yang diperoleh adalah F sebesar 5,427 dengan signifikansi 0.024. Nilai yang diperoleh tersebut lebih besar dari taraf signifikan $\alpha=0.05$, sehingga dapat disimpulkan bahwa semua varians berasal dari populasi yang tidak homogen. Sedangkan pada nilai $t$ diperoleh nilai sebesar 3,476 dengan signifikansi sebesar 0.001 . Nilai signifikansi ini lebih kecil daripada 0.05 (sig. $>0.05$ ) sehingga dapat disimpulkan bahwa terdapat pengaruh pengondisian gelombang otak zona alfa pada apersepsi pembelajaran terhadap motivasi belajar Biologi siswa.

\section{Motivasi Belajar Biologi Siswa dengan Perlakuan Pengondisian Gelombang Otak Zona Alfa pada Apersepsi Pembelajaran}

Hasil analisis data motivasi belajar siswa dengan pengondisian gelombang otak zona alfa pada apersepsi pembelajaran terhadap motivasi belajar Biologi siswa pada kelas eksperimen sebanyak 22 orang diperoleh skor maksimum 114,00 sedangkan skor minimum 90,00 dan rata-rata 101,27 dan standar deviasi sebesar 6,48 varians 
sebesar 41,99 sehingga diperoleh jumlah total 2228,00. Kategori motivasi belajar sangat tinggi berada pada persentase $95,45 \%$ dan kategori motivasi belajar tinggi berada pada persentase $4,54 \%$ sehingga dapat disimpulkan bahwa motivasi belajar Biologi siswa dikategorikan tinggi melalui pengondisian gelombang otak zona alfa pada apersepsi pembelajaran.

\section{Motivasi Belajar Biologi Siswa Tanpa Pengondisian Gelombang Otak Zona Alfa (Metode Konvensional)}

Hasil analisis data motivasi belajar siswa tanpa pengondisian gelombang otak zona alfa pada apersepsi pembelajaran (metode konvensional) pada kelas kontrol kelas XI IPA 1 dengan jumlah sampel 25 diperoleh skor maksimum adalah 108,00 dan skor minimum yaitu 67,00 dengan nilai rata-rata 91,52 dan standar deviasi 11,66. Sehingga diperoleh jumlah total 2288,00. Kategori motivasi belajar Biologi sangat tinggi sebanyak $84,00 \%$ dan kategori tinggi $16,00 \%$ sehingga dapat disimpulkan bahwa motivasi belajar Biologi siswa pada kelas kontrol lebih rendah daripada motivasi belajar Biologi siswa kelas eksperimen.

\section{Pengaruh Pengondisian Gelombang Otak Zona Alfa pada Apersepsi Pembelajaran terhadap Motivasi Belajar Biologi Siswa}

Berdasarkan hasil penelitian dan analisis data serta pembahasan sebelumnya dapat diketahui bahwa motivasi belajar Biologi siswa pada kelas eksperimen (XI IPA 2) memiliki motivasi belajar yang lebih tinggi dibandingkan motivasi belajar Biologi siswa pada kelas kontrol (XI IPA 1) sehingga dapat disimpulkan bahwa terdapat pengaruh pengondisian gelombang otak zona alfa pada apersepsi pembelajaran terhadap motivasi belajar Biologi siswa. Hal ini dapat dilihat pada nilai rata-rata kelas eksperimen (XI IPA 2) sebesar 130,50\% sedangkan kelas kontrol (XI IPA 1) nilai ratarata sebesar $122,20 \%$.

Terdapat pengaruh pengondisian gelombang otak zona alfa pada apersepsi pembelajaran terhadap motivasi belajar Biologi siswa terbukti setelah dilakukan uji hipotesis, di mana hasil yang diperoleh yaitu nilai $\mathbf{t}_{\text {Hitung }}=3,61$ dan $\mathbf{t}_{\text {Tabel }}=2,06$. Hal ini terbukti setelah dilakukan uji hipotesis, di mana hasil yang diperoleh yaitu nilainilai $\mathrm{t}$ hitung sebesar 3,61> $\mathrm{t}$ tabel $=2,06$ sehingga dapat disimpulkan bahwa $\mathrm{H}_{0}$ ditolak dan $\mathrm{H}_{1}$ diterima, sehingga secara keseluruhan terdapat perbedaan yang signifikan antara kelas eksperimen dengan pengondisian gelombang otak zona alfa pada apersepsi pembelajaran dengan kelas kontrol dengan metode konvensional.

Pengondisian gelombang otak zona alfa pada apersepsi pembelajaran pada penelitian ini dilakukan dengan mengondisikan siswa santai dan rileks untuk dan selama proses belajar pada tahap awal sebelum pelajaran dimulai perlakuan awal yang diberikan berupa memperdengarkan musik klasik The universal (The great escape) dari Blur sehingga semangat siswa tergugah. Kemudian setelah siswa siap untuk belajar maka pelajaran dimulai dengan menyampaikan tujuan dan tahapan pembelajaran kemudian mereview pembelajaran sebelumnya dan melakukan apersepsi yakni menghubungkan apa yang telah menjadi pemahaman awal siswa kemudian diarahkan ke 
materi/konsep yang akan dipelajari sehingga melalui apersepsi siswa dapat dengan mudah untuk memasuki dan memulai pembelajaran dengan konsep yang baru.

Apersepsi dilakukan dengan berbagai tahapan yang pada intinya bertujuan untuk menarik perhatian siswa dengan menghubungkan pemahaman awal siswa dengan pelajaran yang akan dipelajari. Dengan adanya apersepsi maka dapat memberikan dasar awal siswa untuk mempelajari materi yang baru, dengan demikian maka apersepsi dapat memberikan kemudahan siswa dalam belajar. Apersepsi merupakan stimulus khusus pada awal belajar yang bertujuan meraih perhatian dari peserta didik. Apersepsi dapat menciptakan pembelajaran efektif karena apersepsi dapat mengantarkan peserta didik pada zona alfa, yaitu kondisi terbaik untuk belajar sehingga peserta didik lebih mudah menyerap materi pelajaran. Apersepsi dilakukan melalui fun story, musik, dan disisipi dengan cerita motivasi atau kisah inspiratif.

Ketika siswa berada dalam kondisi alfa, maka konsentrasi siswa hanya berfokus pada satu persoalan. Kondisi gelombang otak zona alfa dapat membangkitkan motivasi belajar siswa karena siswa berada dalam suasana santai dan rileks belajar hal ini terwujud dengan mengupayakan kondisi yang disenangi oleh siswa dan menciptakan peran aktif siswa dalam proses belajar serta keakraban antara guru dan siswa dan kondisi rileks dalam belajar sehingga tidak adanya tekanan dan rasa takut siswa dalam belajar. Zona alfa dapat meningkatkan hormon endorfin yaitu hormon yang bekerja untuk mengurangi rasa lelah, cemas dan menjadikan orang merasa bahagia, siswa merasa bahagia dan tidak takut akan risiko gagal dalam menerima materi pembelajaran. Zona alfa juga meningkatkan relaksasi yang sangat berperan untuk menambahkan oksigen ke otak, pertukaran udara yang lebih baik dan sebagai bahan bakar untuk berpikir lebih dalam (belajar) sehingga melalui fun story dapat mengurangi stres siswa dari risiko gagal saat menerima pelajaran, meningkatkan emosi positif siswa dan selalu merasa nyaman saat belajar.

\section{SIMPULAN}

Pengondisian gelombang otak zona alfa pada apersepsi pembelajaran adalah menciptakan suasana belajar yang memungkinkan siswa berada dalam kondisi nyaman dan santai dalam belajar. Upaya tersebut dilakukan melalui musik klasik dan fun story. Pengondisian zona alfa pada apersepsi pembelajaran sangat penting karena menit-menit pertama pembelajaran menentukan jam-jam selanjutnya selama belajar.

Motivasi belajar Biologi siswa kelas XI IPA Madrasah Aliyah Negeri 3 Makassar dengan pengondisian gelombang otak zona alfa pada apersepsi pembelajaran pada kelas eksperimen kelas XI IPA 2 tergolong kategori motivasi belajar sangat tinggi. Sedangkan motivasi belajar siswa metode konvensional pada kelas kontrol kelas XI IPA 1 kategori motivasi belajar Biologi di bawah motivasi belajar Biologi siswa kelas eksperimen.

Pengaruh pengondisian gelombang otak zona alfa pada apersepsi pembelajaran terhadap motivasi belajar Biologi siswa menunjukkan bahwa terdapat perbedaan motivasi belajar Biologi siswa antara siswa yang diberikan perlakuan dengan siswa tan- 
pa perlakuan (metode konvensional) yakni siswa dengan perlakuan memiliki motivasi belajar lebih tinggi.

\section{DAFTAR PUSTAKA}

Arikunto, S. (2000). Manajemen Penelitian. Jakarta: PT Rineka Cipta.

Chatib, M. (2014). Gurunya Manusia. Bandung: Kaifa.

Dimyati, M. (2001). Belajar dan Pembelajaran. Jakarta: Rineka Cipta.

Djamarah, S. B. (2008). Psikologi Belajar. Jakarta: Rineka Cipta.

Emzir. (2007). Metodologi Penelitian Pendidikan: Kuantitaif dan Kualitatif. Jakarta: Rajawali Pers.

Ismail, M. I. (2012). Orientasi Baru dalam Ilmu Pendidikan. Makassar: Alauddin University Press.

Muhammad, N. (2011). Gelombang Otak Manusia. Jogjakarta: Diva Press.

Mustami, M. K. (2016). Metodologi Penelitian Pendidikan. Yogyakarta: Aynat Publishing.

Narbuko, C. \& A. A. (2013). Metodologi Penelitian. Jakarta: Bumi Aksara.

Nasution, S. (2010). Dikdaktik Asas-asas Mengajar. Jakarta: PT Bumi Aksara.

Pasiak, T. (2003). Revolusi IQ/EQ/SQ: Antara Neurosains dan Al-Qur'an. Bandung: Mizan.

Sugiyono. (2008). Metode Penelitian Pendidikan: Pendekatan Kuantitatif, Kualitatif, dan R $\mathcal{E} D$. Bandung: Alfabeta.

Tafsir, A. (2010). Ilmu Pendidikan dalam Perspektif Islam. Bandung: Remaja Rosdakarya.

Usman, M. U. (1993). Upaya Optimalisasi Kegiatan Belajar Mengajar. Bandung: Remaja Rosdakarya. 